\title{
Efektivitas Pembelajaran Daring Selama Masa Pandemi Covid-19 Di Sekolah Menengah Pertama Kota Palangka Raya
}

\author{
Gunarjo S Budi \\ Program Studi Pendidikan Fisika, FKIP Universitas Palangka Raya \\ Jl. Yos Sudarso Induk, Palangka Raya, Indonesia \\ Email : gunarjosbudi@gmail.com
}

Diterima: 12-11-2021; Diperbaiki:22-01-2022; Disetujui:04-02-2022

\begin{abstract}
ABSTRAK
Penelitian ini bertujuan untuk mengetahui keefektivan pembelajaran daring pada mata pelajaran IPA di masa pandemi COVID-19 berdasarkan respon guru dan siswa dari empat Sekolah Menengah Pertama (SMP) yang berada di kota Palangka Raya. Penelitian ini menggunakan pendekatan kuantitatif dengan metode survei. Teknik pengumpulan data dalam penelitian ini menggunakan angket. Pengisian angket dilakukan secara online dalam bentuk Google Form yang dibagikan kepada para responden. Responden pada penelitian ini adalah siswa dari empat Sekolah Menengah Pertama (SMP) di kota Palangka Raya yang berjumlah 80 orang. Penelitian ini menunjukkan bahwa ada $48,75 \%$ siswa yang menyatakan ingin pembelajaran dilaksanakan secara tatap muka langsung, namun $63,75 \%$ siswa merasa senang dengan pembelajaran secara daring, dan 42,5\% siswa menyatakan cukup serius dalam mengikuti proses pembelajaran secara daring. Selain itu, hasil belajar siswa dengan pembelajaran daring diperoleh sebanyak 77,5\% siswa yang memperoleh nilai diatas 75, sehingga dapat dikatakan pembelajaran daring ini cukup efektif.

Kata Kunci : Efektivitas, Pandemi COVID-19, Pembelajaran Daring.
\end{abstract}

\section{PENDAHULUAN}

Akhir tahun 2019 dunia dibuat panik dan takut dengan sebuah virus yang mematikan. Virus tersebut menyebar dan semakin meluas pada awal tahun 2020. Virus tersebut adalah corona virus disease 2019 atau yang lebih dikenal dengan COVID-19. Virus ini pada awalnya ditemukan di Wuhan, China yang kemudian sampai saat ini sudah menyebar hampir di seluruh pelosok dunia (Shi, et al., 2020). Virus ini memiliki jangka watu penyebaran yang cukup cepat dengan masa inkubasi rata-rata 5-6 hari dengan masa inkubasi terpanjang selama 14 hari (Yurianto, Ahmad, 2020). COVID-19 hingga saat ini terkonfirmasi telah melanda 209 negara di dunia dengan kasus sebanyak 106.865 .118 yeng menyebabkan kematian sebanyak 2.331.670, dan angka sembuh mencapai 78.581 .766 orang. Indonesia menempati urutan ke-19 kasus positif COVID-19, yaitu sebanyak 1.166.079 dengan jumlah kasus sembuh 963.028 dan meninggal sebanyak 31.763 orang, berdasarkan data per 8 February 2021 (Worldometers, 2021). Sebuah tindakan perlu dilakukan untuk mengantisipasi penularan virus COVID-19,

Mengantisipasi penularan virus tersebut, pemerintah telah mengeluarkan berbagai kebijakan, seperti kebijakan untuk pembatasan interaksi atau physical 
distancing. Physical distancing merupakan salah satu cara yang ditetapkan oleh pemerintah guna memutus tali rantai penyebaran COVID-19 yang dilakukan dengan cara pembatasan interaksi masyarakat (Mustakim, 2020). COVID-19 juga berdampak langsung ke dunia pendidikan yang mengakibatkan pembelajaran dengan tatap muka secara langsung tidak mungkin dilakukan. Hal tersebut mengakibatkan terpaksanya pembelajaran yang harus dilaksanakan dengan jarak jauh yang sebelumnya belum pernah dilaksanakan secara serentak (Sun et al, 2020). Pembelajaran daring menjadi salah satu alernatif yang dapat dilakukan untuk mengatasi permasalahan akibat pandemi COVID-19 tersebut (Ali Sadikin, 2020). Siswa tetap dapat mengikti proses pembelajaran melalui proses pembelajaran secara daring menjadi solusi yang dianjurkan oleh Pemerintah.

Pemerintah Republik Indonesia melalui Kementerian Pendidikan dan Kebudayaan memberlakukan kebijakan pembelajaran daring atau online untuk memperlambat penyebaran COVID-19, sekaligus memastikan agar aktivitas pembelajaran dapat tetap berlangsung meskipun dalam kondisi pandemi (Wahyono \& Husamah, 2020). Menteri Pendidikan dan Kebudayaan Republik Indonesia mengeluarkan surat edaran Nomor 3 Tahun 2020 tentang pencegahan COVID-19 pada satuan pendidikan. Menindaklanjuti hal tersebut, berbagai sekolah dan perguruan tinggi di Kota Palangka Raya juga mengeluarkan kebijakan terkait hal tersebut. Sekolah-sekolah dan perguruan tinggi di kota Palangka Raya menerapkan sistem pembelajaran dan perkuliahan secara daring dengan memanfaatkan berbagai platform.

Platform yang dapat digunakan untuk pembelajaran daring diantaranya yaitu Zoom Meeting, Quiper, Ruang Guru, Google Suite For Education, Zenius dan masih banyak lagi. Pembelajaran daring dalam penerapannya dapat menggabungkan beberapa platform menjadi satu. Sebagai contoh menggunakan Zoom sebagai media live streaming, Google Classroom sebagai media interaksi kelas virtual berbasis web, dan WhatsApp group untuk mendukung interaksi yang lebih ringkas dalam kelas daring berbasis platform chat. Penggunaan beberapa platform ini dapat mengacu pada penelitian terkait pembelajaran daring.

Proses pembelajaran IPA menekankan pemberian pengalaman langsung untuk mengembangkan kompetensi agar menjelajahi dan memahami alam sekitar secara ilmiah (Chan, 2017). Salah satu ilustrasi yang mampu memberikan informasi penjelasan kepada siswa ialah demontrasi (Fatimah, 2017). Berdasarkan hal tersebut, guru menggunakan whatsapp sebagai aplikasi pembelajaran online dengan dibantu video demontrasi pada beberapa materi yang membutuhkan praktik. Materi pembelajaran diberikan guru kepada siswa melalui aplikasi whatsapp dalam bentuk powerpoint, materi bacaan, dan video demontrasi singkat. Hal tersebut yang mendasari penulis untuk mengetahui keefektivan pembelajaran daring pada mata pelajaran IPA di masa pandemi COVID-19 berdasarkan respon guru dan siswa dari empat Sekolah Menengah Pertama (SMP) yang berada di kota Palangka Raya. Penelitian ini memiliki 
kontribusi sebagai evaluasi dan acuan perbaikan pembelajaran pada pelaksanaan pembelajaran daring berikutnya. Hasil penelitian ini juga dapat dijadikan contoh dan rujukan bagaimana melakukan analisis pembelajaran di masa pandemi pada tingkat Sekolah Menengah Pertama (SMP) sederajat.

\section{METODE PENELITIAN}

Penelitian ini menggunakan pendekatan kuantitatif dengan metode survei. Penelitian kualitatif adalah penelitian dimana peneliti ditempatkan sebagai instrumen kunci, teknik pengumpulan data dilakukan secara penggabugan dan analisis data bersifat induktif (Sugiono, 2010: 9). Menurut Poerwandari (2005), penelitian kualitatif menghasilkan dan mengolah data yang sifatnya deskriptif, seperti transkripsi wawancara dan observasi. Kirk dan Miller dalam Moleong (2002: 3) mendefinisikan penelitian kualitatif sebagai cara untuk melakukan pengamatan langsung pada individu dan berhubungan dengan orang-orang tersebut untuk mendapatkan data yang digalinya. Survei dilakukan untuk bahan evaluasi pembelajaran IPA di masa pandemi COVID-19. Penelitian ini dilakukan pada semester ganjil tahun akademik 2020/2021.

Teknik pengumpulan data dalam penelitian ini menggunakan angket. Pengisian angket dilakukan secara online dalam bentuk Google Form yang dibagikan kepada para respnden. Survei dilakukan dengan alasan agar dapat diketahui secara pasti dan akurat tentang keefektivan pembelajaran yang dilakukan secara daring di beberapa Sekolah Menengah Pertama (SMP) di kota Palangka Raya.

Responden pada penelitian ini adalah siswa dari empat Sekolah Menengah Pertama (SMP) di kota Palangka Raya yang berjumlah 80 orang. Komponen dalam angket terdiri dari identitas responden serta pertanyaan untuk mengetahui proses pelaksanaan pembelajaran daring selama masa pandemi COVID-19 dan kendala yang dihadapi siswa (5 pertanyaan). Data yang sudah terkumpul dari angket tersebut selanjutnya akan dikelompokkan ke dalam tabel, dipersentasekan, lalu ditampilkan dalam bentuk diagram, dan kemudian dianalisis.

\section{HASIL DAN PEMBAHASAN}

Responden dalam penelitian ini diminta untuk mengisi angket yang berisi beberapa pertanyaan yang relevan untuk mengetahui seberapa besar efektifitas pembelajaran secara daring. Responden diminta untuk mengisi angket secara jujur sesuai dengan proses pembelajaran yang berlangsung. Beberapa pertanyaan yang diajukan kepada responden adalah sebagai berikut.

1. Apakah anda senang mengikuti pebelajaran yang dilaksanakan secara daring?

Pertanyaan ini diajukan untuk melihat antusiasme siswa dalam mengikuti pembelajaran yang dilaksanakan secara daring. Antusiasme siswa terhadap pembelajaran daring perlu diukur agar ke depannya bisa dilakukan evaluasi apakah pelaksanaan pembelajaran secara daring ini efektif atau justru membuat siswa 
kurang senang dalam proses pembelajaran. Tingkat antusiasme siswa terhadap proses pembelajaran juga mempengaruhi kualitas pembelajaran itu sendiri. Berikut merupakan hasil survei terhadap tingkat antusiasme siswa terhadap pembelajaran secara daring:

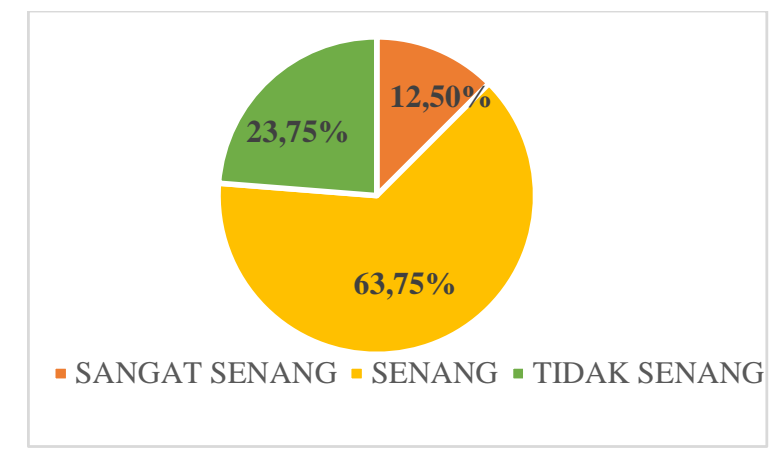

Gambar 1. Antusiasme dalam pembelajaran

Berdasarkan Gambar 1 tentang antusiasme siswa terhadap pembelajaran yang dilaksanakan secara daring diketahui bahwa sebanyak 12,50\% siswa merasa sangat senang dengan pembelajaran daring, 63,75\% menyatakan senang dengan pembelajaran secara daring dan $23,75 \%$ menyatakan tidak senang dengan pembelajaran yang dilaksanakan secara daring. Hal ini dapat disimpulkan bahwa pembelajaran secara daring cukup menarik antusiasme siswa walapun basih cukup banyak siswa yang kurang senang dengan pembelajaran secara daring ini.

2. Media apa yang digunakan selama pembelajaran dilaksanakan secara daring?

Pertanyaan ini diajukan agar diketahui aplikasi atau platform apa yang paling banyak digemari oleh siswa selama proses pembelajaran secara daring. Cukup banyak pilihan aplikasi yang dapat digunakan dalam pelaksanaan pembelajaran secara daring. Penentuan aplikasi yang digunakan akan menggambarkan efektivitas pembelajaran. Aplikasi yang efektif akan memungkinkan pembelajaran yang dilaksanakan 2 arah seperti Zoom Meeting. Berikut merupakan hasil survei terhadap aplikasi yang digunakan dalam pembelajaran daring.

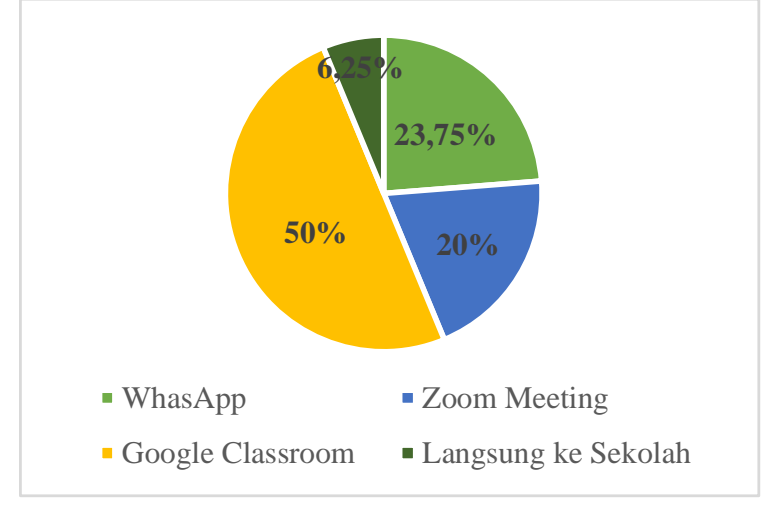

Gambar 2. Aplikasi yang disukai yang disukai 
Berdasarkan Gambar 2 tentang media daring yang digunakan dalam proses pembelajaran diketahui bahwa sebanyak 50\% siswa menyukai pembelajaran menggunakan google classroom. Aplikasi google classroom padahal tidak bisa digunakam ntuk pembelajaran face to face berbeda dengan zoom meeting yang lebih efektif hanya memperoleh persentase sebesar $20 \%$. Sisa nya $23,75 \%$ menykai menggunakan aplikasi Whatsapp dan 6,25\% nya lebih menyukai pembelajaran dilaksanakan langsung.

3. Apa yang menjadi hambatan atau kekurangan selama proses pembelajaran secara daring?

Pertanyaan ini diajukan untuk mengetahui faktor apa saja yang menjadi penyebab tidak efektif nya pembelajaran secara daring. Beberapa faktor tersebut diantaranya stabilitas jaringan, kuota internet, fasilitas yang tidak mendukung dan kurangnya waktu belajar. Pertanyaan ini dapat menjawab faktor yabf dominan dalam menghambat proses pembelajaran secara daring. Berikut adalah hasil survei tentang hambatan atau kekurangan dalam pembelajaran daring.

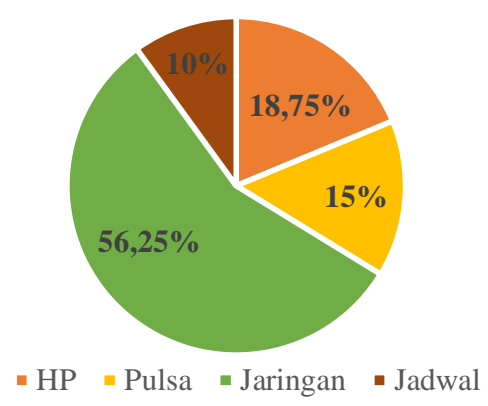

Gambar 3. Kendala Pembelajaran Daring

Berdasarkan Gambar 3 tentang hambatan atau kekurangan dalam pembelajaran daring diketahui bahwa 56,25\% responden terkendala pada jaringan yaitu kurang stabilnya jaringan internet yang ada sehingga terhambatnya pembelajaran yang dilaksanakan. $18,75 \%$ responden menyatakan bahwa yang menjadi hambatan yaitu HP atau fasilitas yang diperlukan dalam pembelajaran secara daring ini kurang mendukung seperti memori penuh, HP rusak dan lain-lain. 15\% responden menyatakan bahwa pembelajaran secara daring terhambat karena faktor pulsa, dimana yang dimaksud di sini yaitu tidak memiliki kota, boros kuota dan lain-lain. Sisanya $10 \%$ responden menyatakan bahwa faktor yang menjadi penghambat yaitu faktor jadawal, dimana yang dimaksud di sini yaitu kurangnya waktu dalam melaksanakan pembelajaran, pembelajaran dilaksanakan tidak sesuai jadwal yang ada dan lain sebagainya. Faktor yang paling dominan disini adalah faktor jaringan, hal ini merupakan hal wajar karena siswa yang mengikuti pembelajaran berada di daerah ataupun tempat yang bereda sehingga koneksi internet yang tidak stabil sangat memungkinkan terjadi di beberapa daerah. 
4. Bagaimana tingkat keseriusan anda selama proses pembelajaran secara daring?

Pertanyaan ini diajukan untuk mengetahui sejauh apa tingkat keseriusan siswa dalam melaksanakan pembelajaran secara daring. Semakin serius siswa dalam mengikuti pembelajaran secara daring, maka semakin efektif pembelajaran tersebut. Berikut adalah hasil suvei mengenai tingkat keseriusan siswa dalam melaksanakan pembelajaran

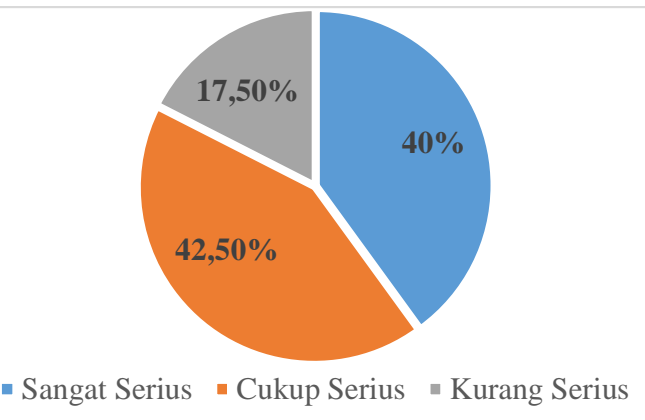

Gambar 4. Keseriusan dalam pembelajaran daring

Berdasarkan Gambar 4 tentang tingkat keseriusan siswa dalam melaksanakan pembelajaran daring dapat diketahui bahwa 42,50\% siswa cukup serius dalam pelaksanaannya. Siswa yang sangat seris dalam pelaksanaan pembelajaran secara daring sebesar $40 \%$ dan sisanya 17,50\% kurang serius. Hal ini menunjukkan bahwa pembelajaran secara daring cukup efektif dalam penerapannya.

5. Manakah yang anda pilih, pembelajaran secara daring atau tatap muka secara langsung?

Pertanyaan ini diajukan untuk mengetahui keinginan siswa dalam proses pembelajaran yang dilaksanakan selama masa pandemi COVID-19 ini. Pilihannya adalah Daring,tatap muka, da kombinasi antara daring dan tatap muka. Pertanyaan ini diajukan agar dapat dketahui kesimpulan dari hasil temuan di lapangan terkait dengan efektivitas pembelajaran daring di masa pandemi COVID-19. Apabila mayoritas responden menjawab daring, maka berarti pembelajaran secara daring ini sangat efektif dan digemari oleh banyak siswa, namun sebaliknya jika mayoritas responden menjawab tatap muka maka berarti pembelajaran secara darini ini tidak efektif dan kurang digemari oleh siswa. Berikut adalah hasil survei mengenaik keinginan siswa di dalam pelaksanaan pembelajaran. 


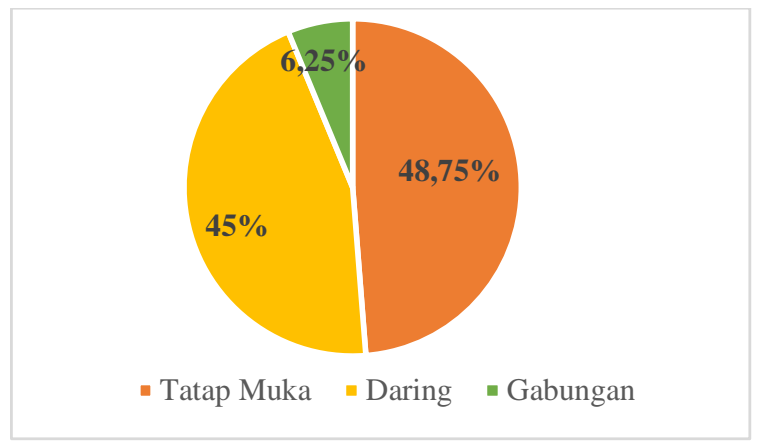

Gambar 5. Metode Pembelajaran yang Lebih Digemari

Berdasarkan Gambar 5 tentang pilihan siswa terhadap metode pembelajaran menunjukkan hasil 48,75\% responden menginginkan pembelajaran dilaksanakan secara tatap muka langsung, $45 \%$ responden menginginkan proses pembelajaran secara daring, dan hanya $6,25 \%$ responden yang menginginkan sebagian proses pembelajaran secara daring. Hal ini menunjukkan bahwa siswa tidak menginginkan proses belajar dilaksanakan secara daring terus-menerus

Selain data yang dikumpulkan dengan menggunakan angket, dalam penelitian ini juga diketahui data berupa hasil belajar siswa selama proses pembelajaran dilaksanakan secara daring. Data hasil belajar siswa dapat dijadikan salah satu tolak ukur untuk menentukan pembelajaran secara daring berlangsung secara efektif atau tidak. Hasil belajar siswa tersebut dapat dilihat pada Gambar 6 .

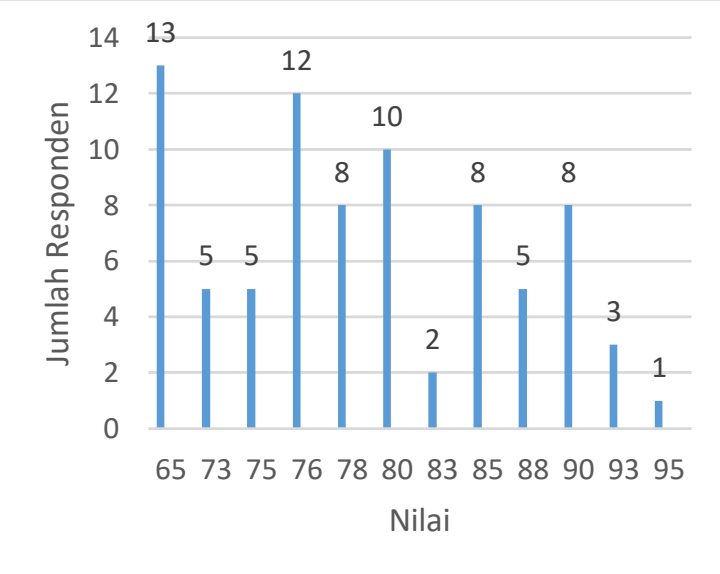

Gambar 6. Data Hasil Belajar Siswa Selama Pandemi

Beradasarkan Gambar 6 tentang hasil belajar siswa yang diperoleh selama masa pandemi dan dilaksanakan pembelajaran daring diketahui bahwa hasil belajar yang diperoleh bervariasi, dengan nilai terendah yaitu 65 dan tertinggi sebesar 95 . Hasil belajar siswa yang dengan nilai di bawah 75 terdapat sebanyak 22,5\% dengan nilai yang diperoleh $65(16,25 \%)$ dan $73(6,25 \%)$. Hasil beajar siswa dengan nilai di atas 75 terdapat sebanyak 77,5\% dengan perolehan nilai $75(6,25 \%), 7615 \%)$, 78 (10\%), 80 (12,5\%), 83 (2,5\%), 85 (10\%), 88 6,25\%), 90 (10\%), 93 (3,75\%), dan 
$95(1,25 \%)$. Hal ini menunjukkan bawa pembelajaran yang dilaksanakan cukup efektif karena hasil belajar siswa yang memperoleh nilai di atas 75 cukup dominan yang berarti cukup banyak pula siswa yang memahami materi yang disampaikan guru.

\section{KESIMPULAN}

Berdasarkan hasil temuan dan pembahasan, dapat disimpulkan bahwa pembelajaran yang dilakukan secara daring di empat Sekolah Menengah Pertama (SMP) di kota Palangka Raya pada Semester Ganjil Tahun Ajaran 2020/2021 berjalan cukup efektif. Hal ini didasarkan pada respon siswa terhadap lima pertanyaan yang merujuk pada proses dan kendala pembelajaran secara daring. Penelitian ini menunjukkan bahwa ada $48,75 \%$ siswa yang menyatakan ingin pembelajaran dilaksanakan secara tatap muka langsung, namun 63,75\% siswa merasa senang dengan pembelajaran secara daring, dan $42,5 \%$ siswa menyatakan cukup serius dalam mengikuti proses pembelajaran secara daring. Selain itu, hasil belajar siswa dengan pembelajaran daring diperoleh sebanyak $77,5 \%$ siswa yang memperoleh nilai diatas 75 , sehingga dapat dikatakan pembelajaran daring ini cukup efektif.

\section{SARAN}

Beberapa kendala utama yang dialami oleh siswa pada saat proses pembelajaran daring yaitu jaringan internet yang lemah dan menghabiskan banyak kuota. Proses pembelajaran secara daring masih harus dioptimalkan sehingga perlu dilakukan evaluasi demi perbaikan proses pembelajaran daring pada periode selanjutnya. Kondisi pandemi COVID-19 menyebabkan perubahan yang sangat signifikan di berbagai aspek kehidupan salah satunya yaitu pendidikan. Proses pembelajaran dalam dunia pendidikan harus dilaksanakan secara daring merupakan efek yang dirasakan akibat pandemi ini, yang mana kondisi ini hampir belum pernah terjadi sebelumnya. Oleh karena itu, diperlukan penelitian mengenai proses pembelajaran daring yang dilakukan secara terus-menerus dan diharapkan mengalami peningkatan dalam pelaksanaannya karena sejauh ini masih banyak kendala yang dihadapi selama proses pembelajaran daring.

\section{DAFTAR PUSTAKA}

Ali Sadikin, A. H. 2020. Pembelajaran Daring di Tengah Wabah COVID-19 . BIODIK: Jurnal Ilmiah Pendidikan Biologi, 6(2), 2014-224.

Chan, F. 2017. Implementasi Guru Menggunakan Metode Permainan Pada Pelajaran IPA di Sekolah. Jurnal Gentala Pendidikan Dasar, 2(1), 106- 123. https://doi.org/10.22437/gentala.v2i1.6821 
Fatimah. 2017. Meningkatkan Hasil Belajar Siswa Dalam Pembelajaran IPA dengan Metode Demonstrasi Dikelas V SDN 10 Biau . Jurnal Kreatif Tadulako Online, 5(4), 85-96.

Moleong, Lexy. J. 2009. Metode Penelitian Kualitatif. Bandung: PT Remaja Rosdakarya.

Mustakim. 2020. Efektivitas Pembelajaran Daring Menggunakan Media Online selama Pandemi COVID-19 pada Mata Pelajaran Matematika. Al asma: Journal of Islamic Education, 2(1), 1-11.

Poerwandari, E. K. 2005. Pendekatan Kualitatif Untuk Penelitian Perilaku Manusia (Edisi Ketiga). Depok: LPSP Fakultas Psikologi Universitas Indonesia.

Shi, H., Han, X., Jiang, N., Cao, Y., Alwalid, O., Gu, J., ... \& Zheng, C. 2020. Radiological findings from 81 patients with COVID-19 pneumonia in Wuhan, China: a descriptive study. The Lancet Infectious Diseases. https://doi.org/10.1016/S1473-3099(20)30086-4.

Sugiono. 2010. Metode Penelitian Pendidikan Pendekatan Kuantitatif, Kualitatif, dan $R \& G$. Bandung: Alfabeta.

Sun, L., Tang, Y., \& Zuo, W. 2020. Coronavirus Pushes Education Online. Nature Materials, 20200205. https://www.nature.com/articles/s41563-020-0678-8.

Yurianto, Ahmad, Bambang Wibowo, K. P. 2020. Pedoman Pencegahan dan Pengendalian Coronavirus Disease (COVID-19). M. I. Listiana Azizah, Adistikah Aqmarina (ed.).

Wahyono, P., \& Husamah, H. 2020. Guru Profesional di masa Pandemi COVID19: Review Implementasi, Tantangan, dan Solusi Pembelajaran Daring. Jurnal Pendidikan Profesi Guru, 1(1). https://doi.org/10.22219/jppg.v1i1.12462

Worldometers. 2020. COVID-19 Coronavirus Pandemic (Last Update: February 08, 2021, 22:30 GMT). Retrived February, 2021, from Coronavirus website: https://www.worldometers.info/coronavirus/ 